\title{
MENINGKATKAN KEMAMPUAN MENGGAMBAR ANAK USIA DINI MELALUI METODE QUANTUM TEACHING
}

\author{
RENTI APRISYAH \\ Universitas Nahdlatul Ulama Indonesia (UNUSIA) \\ Jln. Taman Amir Hamzah, Menteng, Jakarta Pusat \\ renti@unusia.ac.id
}

\begin{abstract}
Abstrak
Penelitian ini memecahkan masalah pada rendahnya kemampuan menggambar anak B1 TK Kemala Bhayangkari 26 Kota Bengkulu melalui metode Quantum Teaching, Metode penelitian yang digunakan adalah penelitian tindakan kelas. Subjek pada penelitian ini adalah anak B1 TK Kemala Bhayangkari 26 Kota Bengkulu yang berjumlah 19 orang anak. Penelitian tindakan ini dilakukan dalam 2 siklus. Pengumpulan data dalam penelitian ini dilakukan melalui observasi dan portofolio. Hasil penelitian ini membuktikan bahwa penerapan metode quantum teaching dapat meningkatkan kemampuan menggambar anak. Pada siklus I rata-rata kemampuan menggambar anak adalah 53\% dan pada siklus 2 rata-rata kemampuan menggambar anak meningkat menjadi $76 \%$.
\end{abstract}

Kata kunci: Menggambar, Metode Quantum Teaching

\section{Pendahuluan}

Pendidikan merupakan faktor penting dalam membentuk individu yang berkualitas, bahkan pemerintah telah menyadari akan pentingnya peranan pendidikan tersebut terhadap kemajuan pembangunan bangsa, karena pembangunan bangsa sangat dipengaruhi oleh kualitas sumber daya manusia yang ada. Oleh karena itu pemerintah mencantumkan pada pasal 31 dalam Undang-Undang Dasar 1945 tentang pendidikan yang berbunyi, (1) Tiap-tiap warga negara berhak mendapatkan pengajaran; (2) Pemerintah mengusahakan dan menyelenggarakan satu sistem pengajaran nasional yang diatur dengan Undang-Undang.
Undang-Undang tersebut, menggambarkan bahwa seluruh warga Negara berhak akan pendidikan tersebut, karena semua orang memiliki bakat dan kemampuan masing-masing yang harus dikembangkan secara optimal sejak dini, hal ini sejalan dengan pendapat Freud dalam Goble (1987: 21) yang menyatakan bahwa arah dasar kehidupan manusia biasanya ditentukan pada usia awal (pada umur lima tahun). Karena pada masa ini dikatakan sebagai masa golden age, atau masa keemasan dimana pada usia ini adalah waktu yang paling pesat untuk mengembangkan semua aspek perkembangan yang ada pada anak. Dryden dan Voss dalam Noorlaila (2010: 19) juga menyatakan bahwa penelitian 
membuktikan $50 \%$ kemampuan belajar seseorang ditentukan pada empat tahun pertama, dan membentuk 30\% yang lain sebelum mencapai usia delapan tahun. Oleh sebab itu pendidikan harus diselenggarakan sedini mungkin guna membentuk generasi penerus bangsa yang unggul.

Dalam Undang-Undang Nomor 20 Tahun 2003 tentang Sistem Pendidikan Nasional Pasal 1 Angka 14 menyatakan bahwa Pendidikan Anak Usia Dini (PAUD) adalah suatu upaya pembinaan yang ditujukan kepada anak sejak lahir sampai dengan usia enam tahun yang dilakukan melalui pemberian rangsangan pendidikan untuk membantu pertumbuhan dan perkembangan jasmani dan rohani agar anak memiliki kesiapan dalam memasuki pendidikan lebih lanjut.

Selain itu PAUD juga merupakan tempat bagi anak-anak mengembangkan kreativitas yang mereka miliki. Anak belajar sambil bermain, bukan hanya kegiatan yang monoton seperti menulis dan berhitung tapi juga belajar seni rupa, seni peran dan peka terhadap lingkungan. Hal ini sejalan dengan konsep kecerdasan majemuk yang dikemukakan oleh Gardner yang meliputi kecerdasan linguistik, logismatematis, Visual-Spasial, musikal, kinestetik, intrapersonal, interpersonal, naturalis dan eksistensial. Oleh karena itu, guru diharapkan dapat menjadi fasilitator agar kecerdasan anak berkembang secara optimal.

Pada masa kanak-kanak, anak cenderung suka berimajinasi dan menuangkannya lewat gambar, perkataan, bahkan seni rupa seperti membangun bentuk dari balok, clay serta tanah liat. Hal tersebut merupakan ciri dari kecerdasaan Visual-Spasial.

Menurut Partini (2010:79) kecerdasan Visual-Spasial diartikan sebagai kemampuan gambar dan keruangan, yaitu kemampuan menciptakan suatu karya berupa gambar, patung dan bangunan yang berasal dari pikiran orang tersebut. Tentu saja pemikiran kreatif akan tumbuh apabila kecerdasan ini dikembangkan secara optimal, selain itu menurut Suyadi (2009:181) kecerdasan Visual-Spasial berkaitan erat dengan kecerdasaan linguistik dan logika matematika, karena karangan dan tulisan yang tanpa ruh kecerdasaan Visual-Spasial tidak akan mampu menemukan hal yang baru, inilah yang menyebabkan penemu memiliki kecerdasaan Visual-Spasial dan menjadi cikal bakal pemikiran kreatif mereka. Hampir semua penemuan spektakuler terutama penemuan teknologi tepat guna lahir dari kecerdasaan ini, oleh sebab itu sangat penting untuk mengembangkan kecerdasaan visual spasial ini sejak dini. 
Menggambar adalah salah satu ciri utama dari anak yang memiliki kecerdasan Visual-Spasial. Aktivitas menggambar dimulai dari pikiran hingga direalisasikan dalam bentuk nyata, oleh karena itu kemampuan menggambar seorang anak dapat mencerminkan kecerdasan VisualSpasial anak tersebut, sehingga guru diharapkan memfasilitasi aktivitas menggambar anak agar hasil yang didapat sesuai dengan yang diharapkan.

Akan tetapi bila aspek perkembangan menggambar anak tidak difasilitasi dengan baik dikhawatirkan akan mengganggu tahapan perkembangan menggambar anak. Hal ini sejalan dengan pendapat Olivia (2011:4) yang menyatakan bahwa aktivitas kreatif yang merangsang otak anak lewat coretan gambar dan warna perlu difasilitasi oleh guru dan orangtua, kebiasaan melarang aktivitas anak dalam mengekspresikan kreativitas seperti menggambar dapat menghambat keterampilan menggambar anak, sehingga kemampuan menggambar anak tidak berkembang secara optimal sesuai dengan tahapan perkembangannya.

Menurut hasil observasi yang dilakukan pada saat PPL di PAUD Kemala Bhayangkari 26 Kota Bengkulu, muncul berbagai permasalahan meliputi: (1) Pembelajaran yang dilakukan kurang merangsang kreativitas, spontanitas dan keberanian anak dalam kegiatan menggambar anak. (2) kemampuan menggambar anak belum sesuai dengan tahapan perkembangannya, dari 20 anak yang terdiri dari 7 orang anak perempuan dan 13 anak laki-laki, hanya 4 anak lakilaki dan 5 anak perempuan yang mampu menggambar sesuai tahap pekembangan.

Oleh karena itu, agar terjadi pembelajaran yang aktif dan menyenangkan guna mengembangkan kecerdasan Visual-Spasial anak yang dilihat dari hasil menggambar anak maka dibutuhkan metode pembelajaran yang aktif dan menyenangkan serta dapat membangun kepercayaan diri anak. Dalam penelitian kali ini bentuk metode pembelajaran yang dilakukan adalah metode Quantum Teaching. Metode Quantum Teaching ini berorientasikan pada teori pendidikan seperti teori percepatan belajar (Lozanov), kecerdasan majemuk (Gardner) dan teori NLP (Grindler dan Bandler) yang memberikan kiat-kiat, petunjuk, strategi, dari seluruh proses yang dapat mempertajam pemahaman dan daya ingat serta membuat belajar sebagai suatu proses yang menyenangkan. Menurut Deporter (2011:32) Quantum Teaching adalah pengubah proses belajar dengan nuansa yang meriah dan menyertakan kaitan interaksi, perbedaan cara belajar dan dinamisasi lingkungan kelas. Sehingga proses belajar menjadi suatu kegiatan yang 
menyenangkan dengan menyesuaikan perbedaan karakteristik anak. Selain itu Deporter dan Hernacki (2011:15) juga menyampaikan bahwa metode Quantum Teaching adalah falsafah belajar yang terbukti efektif untuk semua umur, sehingga model ini dapat pula diterapkan pada pembelajaran di PAUD.

Dari uraian di atas maka perlu adanya perbaikan yang lebih inovatif dengan menggunakan pembelajaran Quantum Teaching untuk mengembangkan kemampuan menggambar anak. Maka peneliti berkeinginan melakukan penelitian tindak kelas dengan judul, "Penerapan Metode Quantum Teaching Untuk Mengembangkan Kemampuan Menggambar Pada Kelompok B3 PAUD Kemala Bhayangkari 26 Bengkulu".

\section{Menggambar pada Anak Usia Dini.}

Menurut Sumanto (2005:15) menggambar adalah proses membuat bentuk dengan cara menggoreskan bendabenda tajam (seperti pensil atau pena) pada bidang datar (seperti kertas, dinding). Menurut Giesecke (2001:3) mengatakan bahwa menggambar adalah proses suatu goresan yang sangat jelas dari benda nyata, sebuah alat komunikasi ide-ide dan rencana yang diusulkan. Berdasarkan pendapat para ahli di atas dapat didefinisikan bahwa menggambar adalah proses goresan pada bidang datar seperti kertas bertujuan sebagai alat menuangkan ide, hasil dari goresan tersebut terciptalah sebuah bentuk yang disebut gambar.

Periodisasi perkembangan menggambar anak dibedakan yaitu (1) masa goresan sekitar usia 2-4 tahun yaitu bentuk yang belum bervariasi meliputi garis mendatar, tegak dan melingkar, (2) masa prabagan sekitar 4-7 tahun yaitu sebuah bentuk atau objek yang tercipta dari proses berimajinasi anak, (3) masa bagan sekitar umur 7-9 tahun merupakan masa menggambar yang lebih sempurna, (4) masa permulaan realisme umur 9-11 tahun dimana anak sudah mulai menggambar dengan mempertimbangkan aspek nyatanya suatu bentuk, dan (50 masa realisme semu umur 11-13 tahun ini adalah masa dimana proses menggambarnya sudah sempurna meliputi variasi garis dan pertimbangan realisme suatu objek (Lowenfeld dalam Sumanto, 2005:31).

Selain itu Papalia (2009:328) juga menjelaskan tahap perkembangan menggambar pada anak, yaitu pada umur 2 tahun adalah masa mencoret-coret secara acak namun memiliki pola, pada usia 3 tahun anak mulai menggambar bentuk bulat, segitiga dll. Pada usia 4-5 tahun adalah tahapan menggambar pictorial yaitu perubahan dari bentuk abstrak dan design menjadi menggambar objek nyata. Perkembangan menggambar anak yang akan diamati adalah tahapan usia 4-5 tahun 
dari tahapan perkembangan tersebut dapat menjadi tolak ukur apakah perkembangan menggambar anak sudah berkembang secara optimal atau belum. Sejalan dengan itu Olivia (2011:96) juga menjelaskan bahwa anak sedikit demi sedikit mengkombinasikan beberapa gambar geometris menjadi gambar yang lebih kompleks, umumnya memasuki usia 4 tahun anak mulai menggambar bentuk yang lebih kompleks, yang berupa gabungan beberapa bentuk geometris sehingga menghasilkan gambar manusia, rumah dan sebagainya. Tahapan inilah yang disebut tahapan piktorial.

Menurut Sumanto

berdasarkan cara pembuatan gambar dibedakan menjadi: (1) menggambar bebas sesuai dengan alat yang digunakan, tanpa menggunakan bantuan mistar, jangka dan sejenisnya, sehingga hasil yang didapatkan dari gambar tersebut, memiliki ciri bebas, kreatif, unik dan individual. menggambar yang dibantu dengan bantuan mistar (penggaris, busur, jangka, sablon gambar/huruf), sehingga hasil yang didapatkan memiliki ciri terikat, statis dan spontan, seperti gambar bentuk, ilustrasi, karikatur dan gambar ornament.

Berdasarkan cara pembuatan gambar di atas, maka cara menggambar yang akan dilakukan pada penelitian ini adalah menggambar bebas. Karena dengan kegiatan menggambar bebas dapat memberikan kesempatan kepada anak untuk menuangkan kreativitas dan imajinasi yang ia miliki tanpa batasan. Sejalan dengan itu Sumanto (2008:49) menambahkan bahwa di TK jenis menggambar bebas itulah yang dilatih, karena mengandung unsur imajinatif dan kreatif. Bahan dan alat yang akan digunakan dalam kegiatan menggambar ini meliputi, buku gambar A4, pensil hitam dan pensil warna.

\section{Metode Quantum Teaching}

Menurut Deporter

(2011:32)

Quantum Teaching adalah metodologi pembelajaran yang digunakan oleh guru untuk merancang dan menyajikan proses belajar yang menarik dengan melibatkan unsur-unsur yang mempengaruhi kesuksesan siswa dalam belajar serta berfokus pada hubungan dinamis dalam lingkungan kelas. Selain itu menurut Sa'ud (2009:125) Quantum Teaching adalah model, strategi, pendekatan dan metode yang digunakan guru untuk merancang suasana pembelajaran yang efektif, menggairahkan dan memiliki keterampilan hidup dengan cara memaksimalkan seluruh potensi dan unsur-unsur yang mempengaruhi kesuksesan belajar anak.

Berdasarkan beberapa pendapat para ahli di atas, maka dapat disimpulkan bahwa Quantum Teaching adalah metode pembelajaran yang digunakan guru dalam 
merancang pembelajaran yang menarik, efektif dan memiliki keterampilan hidup dengan melibatkan unsur yang mempengaruhi kesuksesan belajar anak. Menurut Deporter (2011:44) unsur-unsur kesuksesan belajar tersebut meliputi, interaksi yang baik antara guru dan siswa, aturan yang disepakati bersama antara guru dan siswa, lingkungan belajar yang kondusif dan menyenangkan, serta rancangan pembelajaran yang terarah.

Pendekatan pada Quantum Teaching berorientasikan pada dampak usaha pengajaran guru lewat interaksi yang baik dengan murid, guru dan murid memiliki hubungan timbal balik yang akan mempengaruhi proses belajar mengajar. Keakraban, semangat dan kerjasama antara guru dan murid akan menciptakan pengalaman belajar yang nyaman dan menyenangkan, dalam hal ini guru harus mampu memberikan sugesti positif dalam kegiatan pembelajaran.

$$
\text { Menurut Deporter }
$$
strategi yang digunakan dalam metode Quantum Teaching ini meliputi, (1) partisipasi dengan mengubah keadaan, dimana guru harus dapat menciptakan suasana dan lingkungan yang mendukung (2) memotivasi dan menumbuhan minat dengan penerapan kerangka rancangan Quantum Teaching yaitu TANDUR (3) rasa kebersamaan dengan menggunakan 8 kunci keunggulan yaitu, integritas, kegagalan awal kesuksesan, bicaralah dengan niat yang baik, hidup disaat ini, komitmen, tanggung jawab, luwes dan keseimbangan. (4) daya ingat dengan menggunakan SLIM-n-BIL yaitu konsep kecerdasan jamak meliputi Spasial, Linguistik, Interpersonal, Musikal, Naturalis, Body kinestetik, Intrapersonal dan Logis-Matematis yang disingkat menjadi SLIM-n-BIL, (5) daya dengar anak didik dengan mengikuti prinsipprinsip komunikasi ampuh, (6) kehalusan transisi dengan MPT (Mempengaruhi Perilaku dengan Tindakan) yaitu strategi yang digunakan ketika fokus dikelas sudah mulai terpecah dan mempengaruhi kondisi murid dengan perilaku atau ajakan yang bertujuan agar anak meniru.

Unsur dalam Quantum Teaching dibagi menjadi dua kategori yaitu: Pertama, konteks adalah latar yang mendukung pembelajaran Quantum Teaching yang meliputi: (a) suasana yaitu keadaan ruangan belajar yang dipengaruhi oleh emosi, suasana yang bagus adalah mengandung unsur niat atau motivasi, hubungan yang baik, kegembiraan dan ketakjuban, pengambilan resiko, rasa saling memiliki dan keteladanan; (b) landasan yang kukuh berperan sebagai bagian penting dalam komunitas belajar, Karena landasan tersebut menjadi pedoman yang menuntun perilaku, membina akhlak dan mengajarkan nilai- 
nilai yang melekat seumur hidup pada diri setiap anak, unsur dalam landasan tersebut meliputi tujuan yang sama, prinsip-prinsip dan nilai-nilai yang sama, keyakinan kuat mengenai belajar mengajar, dan kesepakatan, kebijakan, prodesur dan peraturan yang jelas; (c) lingkungan yang mendukung, unsurnya meliputi lingkungan sekeliling, alat bantu, pengaturan bangku. aroma, dan musik; (d) rancangan belajar yang mendukung, menggunakan kerangka belajar Quantum Teaching yang disebut TANDUR.

Kedua, isi adalah keterampilan menyampaikan bahan ajar, dan strategi yang dibutuhkan anak untuk bertanggung jawab adalah sebagai berikut: (a) penyajian yang prima, yaitu cara menyampaikan materi dengan mencocokan gaya belajar anak, memunculkan komunikasi yang ampuh dan komunikasi nonverbal; (b) fasilitas yang luwes yaitu guru sebagai fasilitator anak tehadap hasil belajar yang diharapkan; (c) keterampilan belajar untuk belajar, merupakan keterampilan yang merangsang cara belajar yang lebih cepat dan efektif dengan memasukan unsur cara kerja otak anak, gaya belajar, kemampuan mengoganisir informasi belajar; (d) keterampilan hidup, yaitu kemampuan untuk membina dan memelihara hubungan baik dengan orang lain. Kemampuan tersebut dikembangkan dengan mengikuti delapan kunci kesuksesan, membangun persaudaraan dan memiliki hubungan yang jenih sesama peserta didik serta guru.

\section{Langkah-Langkah}

Pembelajaran

\section{Quantum Teaching}

Menurut Deporter (2011:88) dalam penerapan unsur-unsur pembelajaran Quantum Teaching maka dibutuhkan langkah-langkah pembelajaran Quantum Teaching yang dikenal dengan TANDUR, yaitu (1) Tumbuhkan: menumbuhkan semangat belajar anak dengan cara memotivasi. (2) Alami: Pengalaman dalam kehidupan nyata tentang materi yang akan disampaikan. (3) Namai: penamaan memuaskan hasrat alami otak untuk memberikan identitas, mengurutkan atau mendefinisikan, penamaan dibangun di atas pengetahuan dan keingintahuan anak saat itu dengan cara berinteraksi melalui percakapan langsung dengan anak. Penamaan adalah saatnya untuk mengajarkan konsep, keterampilan berpikir dan strategi belajar. (4) Demonstrasikan: guru memberikan kesempatan kepada siswa untuk mencoba menerapkan kembali pengalaman dalam kegiatan pembelajaran yang baru dengan nuansa potensi yang mereka miliki. (5) Ulangi: pengulangan memperkuat koneksi saraf dan menumbuhkan rasa"aku tahu bahwa aku tahu." Langkah ini merupakan pemantapan materi yang didapat oleh masing-masing individu anak. (6) Rayakan: memberikan 
penghargaan atas proses dan hasil belajar anak mengajarkan kepada anak untuk menghormati usaha, ketekunan, dan kesuksesan.

Dalam penerapan langkah-langkah TANDUR tersebut seorang guru harus memperhatikan aspek-aspek sebagai berikut. Pertama, semangat belajar anak. Menurut Farchanah (2010:2) kurangnya minat dan semangat anak dalam belajar menyebabkan kurangnya perhatian, partisipasi dan usaha dalam kegiatan pembelajaran, sejalan dengan itu Davis dalam Rizkina (2013:15) juga menyatakan bahwa kurangnya partisipasi anak menunjukan kurangnya minat serta semangat anak, partisipasi tersebut melibatkan mental dan emosi seorang anak, sehingga pada kegiatan pembelajaran berlangsung akan terlihat semangat anak belajar dari respon yang ia berikan berupa keceriaan dan keaktifan anak dalam mengikuti proses pembelajaran.

Kedua, kegiatan diskusi. Menurut Rizkina (2013:19) diskusi adalah kegiatan teratur dan terarah dalam kelompok kecil maupun besar untuk mendapatkan suatu keputusan mengenai suatu masalah. Sehingga anak yang aktif dalam kegiatan diskusi ini menunjukan pemahamannya terhadap materi yang disampaikan. Menurut Hollingworth dan Lewis dalam Rizkina (2013:19) menjelaskan bahwa anak yang aktif dalam pembelajaran seperti kegiatan diskusi adalah anak yang terlibat terus-menerus dengan baik fisik maupun mental dalam pembelajaran, sehingga anak yang aktif dalam kegiatan diskusi menunjukan keaktifannya dalam menjawab dan bertanya dalam kegiatan diskusi.

Ketiga, kegiatan demonstrasi. Menurut Amanah (2011:10) dengan melibatkan kegiatan demonstrasi dalam kegiatan pembelajaran, maka guru telah memfungsikan seluruh alat indra anak. Sejalan dengan itu Amanah juga menyatakan bahwa dalam kegiatan demonstrasi harus memperhatikan hal-hal seperti berpusat pada satu topik, mengurangi kesalahan pada saat demonstrasi berlangsung dan keaktifan anak dalam kegiatan.

Keempat, anak menceritakan kembali pengalaman pembelajaran yang ia dapat, bercerita merupakan kegiatan yang menjelaskan terjadinya suatu hal, peristiwa dan kejadian yang dialami sendiri atau orang lain, (Wulan, 2011:10)..

Kelima, kepercayaan diri serta menunjukan kebanggaan terhadap hasil karya yang anak miliki. Menurut Mudlifatin dan Rohita (2013:3) seorang anak yang percaya diri dapat menyelesaikan tugasnya dengan baik sesuai dengan tahapan perkembangannya, merasa berharga dan memiliki kebangaan serta kemampuan untuk meningkatkan prestasinya. Seorang anak yang memiliki 
kebanggaan terhadap hasil karyanya menunjukan bahwa ia mampu menguasai pembelajaran dengan baik sehingga memunculkan rasa percaya diri yang baik pada anak. Hal tersebut terwujud dalam tingkah laku seperti berani menunjukan hasil karyanya kepada orang lain.

\section{Metode Penelitian}

Penelitian ini menggunakan metode penelitian tindakan (action research) yang bersifat partisifatif dan kolaboratif. Desain penelitian tindakan yang digunakan dalam penelitian ini adalah model Kurt Lewin yang menggunakan empat komponen meliputi, perencanaan, tindakan, observasi dan refleksi.
Instrumen pengumpulan data yang digunakan dalam penelitian ini adalah non tes, yaitu: (1) Lembar observasi, (2) Portofolio, (3) Dokumentasi, dengan menggunakan teknik pengumpulan data berupa observasi dan portofolio.

Teknik analisis data yang dilakukan dalam penelitian ini yaitu teknik analisis data kualitatif dan teknik analisis data kuantitatif. Teknik tersebut menggunakan pendapat Mills dan Huberment yang terdiri dari: data collection, data reduction, data display dan data conclusing drawing/verification.

\section{Hasil Penelitian dan Pembahasan}

Siklus I

Tabel 1. Hasil Kerja Menggambar Anak Secara Klasikal

\begin{tabular}{|c|c|c|c|c|}
\hline \multirow{2}{*}{$\begin{array}{c}\text { Aspek yang diteliti } \\
\text { Pembetukan kalimat } \\
\text { dalam isi bicara }\end{array}$} & \multirow[b]{2}{*}{ Kriteria } & \multicolumn{2}{|c|}{ Hasil } & \multirow{2}{*}{$\begin{array}{r}\text { Aspek yang } \\
\text { memperoleh } \\
\text { ketuntasan }\end{array}$} \\
\hline & & $\mathbf{F}$ & $\%$ & \\
\hline \multirow{5}{*}{$\begin{array}{l}\text { Anak menggambar bentuk } \\
\text { seperti aslinya }\end{array}$} & Sangat Baik & 10 & 53 & \multirow{6}{*}{$53 \%$} \\
\hline & Baik & - & - & \\
\hline & Cukup & 9 & 47 & \\
\hline & Kurang & - & - & \\
\hline & $\begin{array}{l}\text { Sangat } \\
\text { Kurang }\end{array}$ & - & - & \\
\hline \multicolumn{2}{|l|}{ Jumlah } & 19 & $100 \%$ & \\
\hline \multirow{4}{*}{$\begin{array}{l}\text { Menggambar dengan } \\
\text { melibatkan unsur warna }\end{array}$} & Sangat Baik & 12 & 63 & \multirow{4}{*}{$63 \%$} \\
\hline & Baik & - & - & \\
\hline & Cukup & 7 & 37 & \\
\hline & Kurang & - & - & \\
\hline
\end{tabular}




\begin{tabular}{|c|c|c|c|c|}
\hline & $\begin{array}{l}\text { Sangat } \\
\text { Kurang }\end{array}$ & - & - & \\
\hline Jumlah & & 19 & $100 \%$ & \\
\hline $\begin{array}{l}\text { Anak menggambar dengan } \\
\text { detail gradasi pada garis } \\
\text { dan warna }\end{array}$ & Sangat Baik & 9 & 47 & $47 \%$ \\
\hline
\end{tabular}

Berdasarkan tabel 1 menunjukan hasil kemampuan menggambar anak dilihat dari aspek menggambar bentuk seperti aslinya terdapat $10(53 \%)$ anak yang mendapatkan nilai sangat baik, sedangkan 9 (47\%) anak lainnya mendapatkan nilai cukup. Perolehan ketuntasaan anak pada aspek menggambar bentuk ini adalah $53 \%$.

Sedangkan pada aspek anak menggambar dengan melibatkan unsur warna, $12(63 \%)$ anak mendapatkan nilai sangat baik dan $7 \quad(37 \%)$ anak mendapatkan nilai cukup, pada aspek ini rata-rata ketuntasan anak adalah $63 \%$. Dan pada aspek anak menggambar dengan detail gradasi pada garis dan warna menunjukan $9(47 \%)$ anak memperoleh nilai sangat baik dan $10 \quad(53 \%)$ anak mendapatkan nilai cukup. Pada aspek anak menggambar dengan gradasi pada garis dan warna ini persentase ketuntasan anak adalah $47 \%$.

\section{Siklus II}

Tabel 2. Hasil Kerja Menggambar Anak Secara Klasikal

\begin{tabular}{|c|c|c|c|c|}
\hline \multirow{2}{*}{$\begin{array}{c}\text { Aspek yang diteliti } \\
\text { Pembetukan kalimat } \\
\text { dalam isi bicara }\end{array}$} & \multirow{2}{*}{ Kriteria } & \multicolumn{2}{|c|}{ Hasil } & \multirow{2}{*}{$\begin{array}{r}\text { Aspek yang } \\
\text { memperoleh } \\
\text { ketuntasan }\end{array}$} \\
\hline & & $\mathbf{F}$ & $\%$ & \\
\hline \multirow{5}{*}{$\begin{array}{l}\text { Anak menggambar } \\
\text { bentuk seperti aslinya }\end{array}$} & Baik sekali & 13 & 68,4 & \multirow{6}{*}{$78,9 \%$} \\
\hline & Baik & 2 & 10,5 & \\
\hline & Cukup & 4 & 21,1 & \\
\hline & Kurang & - & - & \\
\hline & $\begin{array}{l}\text { Kurang } \\
\text { Sekali }\end{array}$ & - & - & \\
\hline \multicolumn{2}{|l|}{ Jumlah } & 19 & 100 & \\
\hline \multirow{2}{*}{$\begin{array}{l}\text { Menggambar dengan } \\
\text { melibatkan unsur warna }\end{array}$} & Baik sekali & 17 & 89 & \multirow{2}{*}{$89 \%$} \\
\hline & Baik & - & - & \\
\hline
\end{tabular}




\begin{tabular}{|c|c|c|c|c|}
\hline & Cukup & 2 & 11 & \\
\hline & Kurang & - & - & \\
\hline & $\begin{array}{l}\text { Kurang } \\
\text { Sekali }\end{array}$ & - & - & \\
\hline \multicolumn{2}{|l|}{ Jumlah } & 19 & 100 & \\
\hline \multirow{5}{*}{$\begin{array}{l}\text { Anak menggambar } \\
\text { dengan detail gradasi } \\
\text { pada garis dan warna }\end{array}$} & Baik sekali & 10 & 53 & \multirow{6}{*}{$79 \%$} \\
\hline & Baik & 5 & 26 & \\
\hline & Cukup & 4 & 21 & \\
\hline & Kurang & - & - & \\
\hline & $\begin{array}{l}\text { Kurang } \\
\text { Sekali }\end{array}$ & - & - & \\
\hline \multicolumn{2}{|l|}{ Jumlah } & 19 & $100 \%$ & \\
\hline
\end{tabular}

Berdasarkan tabel 2 hasil kerja menggambar anak menunjukan bahwa pada aspek kemampuan menggambar bentuk seperti aslinya anak yang mendapatkan nilai sangat baik berjumlah $13(68,4 \%)$ orang, yang mendapatkan nilai baik berjumlah $2(10,5 \%)$ orang dan 4 $(21,1 \%)$ orang anak mendapatkan nilai cukup. Pada aspek menggambar bentuk ini ketuntasan anak adalah 78,9\%. Pada aspek menggambar dengan melibatkan unsur warna menunjukan bahwa terdapat 17 (89\%) anak mendapatkan nilai baik sekali dan 2 anak mendapatkan nilai cukup dengan $11 \%$.

Menurut Giesecke (2001:3) menggambar adalah proses suatu goresan yang sangat jelas dari benda nyata, sebuah alat komunikasi ide-ide dan rencana yang diusulkan. Oleh karena itu agar anak dapat menciptakan gambar yang baik maka perlu kondisi pembelajaran yang nyaman dan menggairahkan minat belajar anak. Menurut Welberg dalam Deporter (2011:54) bahwa anak akan lebih banyak belajar bila pembelajarannya memuaskan, menantang dan ramah serta mereka mempunyai kesempatan untuk mengambil keputusan.

Hasil pengamatan pada siklus 1 menunjukan bahwa anak belum aktif dalam mengikuti pembelajaran Quantum Teaching, seperti semangat anak dalam melakukan kegiatan pembelajaran secara keseluruhan, hal ini terjadi dikarenakan guru masih kurang memiliki keluwesan dalam mengajar dan membina hubungan baik dengan anak sehingga kurang bisa menarik minat anak dalam pembelajaran, sehingga aktivitas belajar anak pada 
pertemuan pertama dan kedua dalam siklus

1 belum ada yang mencapai kriteria ketuntasan hal ini pun berpengaruh pada hasil kerja menggambar anak, belum ada anak yang mencapai kriteria ketuntasan, menurut Deporter (2011:55) untuk menarik keterlibatan anak, guru harus membangun hubungan dengan cara menjalin rasa simpati dan saling pengertian.

Ketika peneliti sudah mulai dekat dengan anak, karena pertemuan yang mulai intens anak-anak sudah mulai menunjukan semangatnya dalam belajar hal ini dilihat dari keterlibatan anak dalam mengikuti pelajaran beberapa anak mulai menunjukan keaktifan dalam kegiatan pembelajaran khususnya kegiatan demonstrasi yang diarahkan oleh guru.

Menurut Sumanto (2008:49) di TK jenis menggambar bebas itulah harus dilatih, dengan kegiatan yang imajinatif dan kreatif, oleh karena itu guru melakukan kegiatan merancang kegiatan demonstrasi yang diharapkan dapat memancing imajinasi dan kreativitas anak dalam menggambar, namun dari semua kegiatan yang dirancang oleh guru memiliki tingkat kesenangan yang berbeda-beda setiap anaknya, sehingga dari kegiatan yang telah dilaksanakan menunjukan kegiatan menonton video adalah kegiatan yang memiliki tingkat antusiasme anak yang paling besar.
Peningkatan aktivitas belajar anak menunjukan peningkatan terhadap kemampuan menggambar anak, terhadap tiga aspek kemampuan menggambar anak yang dinilai meliputi menggambar bentuk, menggambar dengan unsur warna dan menggambar dengan gradasi menunjukan bahwa aspek menggambar dengan detail gradasi pada garis dan warna pada hasil pengamatan selalu mendapatkan nilai yang lebih kecil dari kedua aspek lainnya. Hal ini disebabkan karena anak dalam kegiatan menggambar lebih banyak menekankan pada menggambar bentuk dan mewarnainya sehingga guru lebih menekankan materi tehnik gradasi kepada anak dibandingkan dengan dua aspek lainnya, walaupun aspek menggambar dengan detail gradasi pada garis dan warna memiliki tingkat ketuntasan yang lebih kecil dibanding aspek yang lain, namun aspek ini akhirnya menunjukan kriteria ketuntasan sebesar $79 \%$ Berdasarkan uraian di atas menunjukan bahwa penerapan metode Quantum Teaching terbukti dapat mengembangkan kemampuan menggambar anak.

\section{Daftar Pustaka}

Armstrong, Thomas. 2005. 7 Kinds of Smart. Jakarta: Gramedia.

Chatib, Munif. 2011. Gurunya Manusia. Bandung: Mizan Pustaka.

Chatib, Minuf. 2013. Kelasnya Manusia. Bandung: Mizan Pustaka. 
Deporter, Bobbi dan Hernacki. 2011. Quantum Learning. Bandung: Kaifa.

Deporter, dkk. 2011. Quantum Teaching. Bandung: Kaifa.

Gardner, Howard. 2003. Kecerdasan Majemuk Dalam Praktek. Jakarta: Interaksara.

Giesecke, dkk. 2001. Gambar Teknik. Jakarta: Erlangga.

Goble, Frank G. 1987. Mahzab Ketiga. Yogyakarta: Kanisius.

Gunawan, Adi W. 2007. Born To Be A Genius. Jakarta: Gramedia.

Halimah, Leny, dkk. 2007. Jurnal: Menumbuh Kembangkan

Kecerdasan Majemuk Siswa SD

Melalui Metodelogi Quantum

Teaching Dalam Pembelajaran

Tematik. Bandung: Universitas

Pendidikan Indonesia diunduh dari http://jurnal.upi.edu/pendidikandasar/view/78 /menumbuh kembangkan -kecerdasan- majemuksiswa-sd-melalui- penerapanmetodologi- quantum -teachingdalam-pembelajaran-tematikdeveloping-multiple-intelligencesof-elementry-student-through-theapplication-of-quantum-teachingmenthod-in-a-thematic-learninghtml pada tanggal 20 Desember 2013 pukul 16.13 WIB.

Hariyadi, Moh. 2009. Statistik Pendidikan Panduan Lengkap dari Design Sampai Analisis Statistik Pendidikan. Jakarta: PT. Prestasi Pustaka.

Khairiah, Icha. 2013. Skripsi: Mengembangkan Kecerdasan Visual-Spasial Melalui Bermain Konstruktif Pada Anak Usia Dini. Bengkulu: Universitas Bengkulu.
Musfiroh, $\quad 2008$. Pengembangan Kecerdasan Majemuk. Jakarta: Universitas Terbuka.

Noorlaila, Ita. 2010. Panduan Lengkap Mengajar PAUD. Yogyakarta: Pinus.

Papalia, Diane E. 2009. Human Develpment. Jakarta: Salemba Humanika.

Partini. 2010. Pengantar Pendidikan Anak Usia Dini. Yogyakarta: Grafindo.

Riko. 2011. Skripsi: Penerapan Metode Quantum Learning Menggunakan Media Social Networking Website Facebook Untuk Meningkatkan Hasil Belajar Siswa Kelas X6 Pada Konsep Suhu Dan Kalor di SMA 1 Talang Empat Bengkulu Tengah. Bengkulu: Universitas Bengkulu.

Sa'ud, Udin Syaefudin. 2009. Inovasi Pendidikan. Bandung: Alfabeta.

Sumanto. 2005. Pengembangan Kreativitas seni Rupa Anak TK. Jakarta: Depdiknas.

Susanti, Irna. 2011. Skripi;Penerapan Strategi Pembelajaran Quantum Playing Untuk Meningkatkan Kreativitas Anak di RA Darul Ma'arif Kab. Semarang. Semarang: Institut Agama Islam Negeri Walisongo

Suyadi. 2009. Anak Yang Menakjubkan. Yogyakarta: Diva Press.

Wardhani, Igak. 2008. Penelitian Tindakan Kelas. Jakarta: Universitas Terbuka

Wortham. 2006. Early Chilhood Curriculum Development. New Jersey: Pearson Prentice Hall.

Yus. Anita. 2005. Penilaian Perkembangan Belajar Anak Taman Kanak-Kanak. Jakarta: Depdiknas. 